\title{
Innovations in nanotechnology for water treatment
}

This article was published in the following Dove Press journal:

Nanotechnology, Science and Applications

6 January 2015

Number of times this article has been viewed

\author{
Ilka Gehrke \\ Andreas Geiser \\ Annette Somborn-Schulz \\ Fraunhofer Institute for \\ Environmental, Safety and Energy \\ Technology UMSICHT, Oberhausen, \\ Germany
}

Correspondence: Ilka Gehrke

Fraunhofer Institute for Environmental, Safety and Energy Technology UMSICHT, Osterfelder Straße 3, 46047 Oberhausen, Germany

Tel +49208 8598 I 260

Fax +49 $2088598 \quad 1295$

Email ilka.gehrke@umsicht.fraunhofer.de

\begin{abstract}
Important challenges in the global water situation, mainly resulting from worldwide population growth and climate change, require novel innovative water technologies in order to ensure a supply of drinking water and reduce global water pollution. Against this background, the adaptation of highly advanced nanotechnology to traditional process engineering offers new opportunities in technological developments for advanced water and wastewater technology processes. Here, an overview of recent advances in nanotechnologies for water and wastewater treatment processes is provided, including nanobased materials, such as nanoadsorbents, nanometals, nanomembranes, and photocatalysts. The beneficial properties of these materials as well as technical barriers when compared with conventional processes are reported. The state of commercialization is presented and an outlook on further research opportunities is given for each type of nanobased material and process. In addition to the promising technological enhancements, the limitations of nanotechnology for water applications, such as laws and regulations as well as potential health risks, are summarized. The legal framework according to nanoengineered materials and processes that are used for water and wastewater treatment is considered for European countries and for the USA.
\end{abstract}

Keywords: nanotechnology, water technology, nanoadsorbents, nanometals, nanomembranes, photocatalysis

\section{Introduction}

The long-term development of the global water situation is closely connected to the growth of the world population and global climate change. Constant growth of the world's population, which is forecasted to be nearly doubled from 3.4 billion in 2009 to 6.3 billion people in 2050, is attended by a predicted needed growth of agriculture production of $70 \%$, by $2050 .{ }^{1}$ Thus, the demand for fresh water is growing dramatically, in particular for food production, since $70 \%$ of the world's freshwater withdrawals are already accounted for by agricultural irrigation. Currently, 64 billion cubic meters of fresh water are progressively consumed each year. ${ }^{2}$

The arid regions of North Africa and nearly half of the European countries (approximately $70 \%$ of the population) are confronted with a lack of water supply. Even industrialized countries like the USA, providing highly innovative technologies for saving and purifying water, show the difficulty of exhausted water reservoirs due to the fact that more water is extracted than refilled. In the People's Republic of China, 550 of the 600 largest cities suffer from a water shortage, since the biggest rivers are immensely polluted and even their use for irrigation has to be omitted, not to mention treatment for potable water. 
A group of leading climate impact researchers have shown that climate change possibly exacerbates the regional and global water scarcity. They predict that global warming of $2{ }^{\circ} \mathrm{C}$ above present temperatures will confront an additional approximately $15 \%$ of the global population with a severe decrease in water resources and will increase the number of people living under absolute water scarcity $\left(<500 \mathrm{~m}^{3}\right.$ per capita per year) by at least another $40 \%$ compared with the effect of population growth alone. ${ }^{3}$

The USA has faced the most terrible drought for the last 50 years. In contrast, in rainy countries, heavy rainfall can lead to erosion and soil run-off, which is why pathogens enter water bodies along with soil components and nutrients. Increased temperatures in air and raw water can affect the drinking water hygiene in respective storage systems as well as in drinking water pipelines, resulting in harmful infectious illnesses. For example, Legionnaire's disease might occur, caused by legionella bacteria that reach a population maximum in warm water of around $40^{\circ} \mathrm{C}$.

In both developing and industrialized countries, a growing number of contaminants like micropollutants are entering the water bodies. Conventional decontamination processes such as chlorination and ozonation consume a high amount of chemical agents and, furthermore, can produce toxic byproducts.

The adaptation of highly advanced nanotechnology to traditional process engineering offers new opportunities for development of advanced water and wastewater technology processes. Here, an overview of recent advances in nanotechnologies for water and wastewater processes is provided, including nanobased materials, processes, and their applications. Besides the promising technological enhancements, the limitations of nanotechnology for water applications, such as laws and regulations as well as potential health risks, are reported.

\section{State of science and technology: nanobased materials, processes, and applications}

Nanomaterials have unique size-dependent properties related to their high specific surface area (fast dissolution, high reactivity, strong sorption) and discontinuous properties (such as superparamagnetism, localized surface plasmon resonance, and quantum confinement effect). These specific nanobased characteristics allow the development of novel high-tech materials for more efficient water and wastewater treatment processes, namely membranes, adsorption materials, nanocatalysts, functionalized surfaces, coatings, and reagents. The most promising materials and applications are highlighted in Table 1.

\section{Adsorption}

Adsorption is the capability of all solid substances to attract to their surfaces molecules of gases or solutions with which they are in close contact. Solids that are used to adsorb gases or dissolved substances are called adsorbents, and the adsorbed molecules are usually referred to collectively as the adsorbate. ${ }^{4}$ Due to their high specific surface area, nanoadsorbents show a considerably higher rate of adsorption for organic compounds compared with granular or powdered activated carbon. They have great potential for novel, more efficient, and faster decontamination processes aimed at removal of organic and inorganic pollutants like heavy metals and micropollutants. In addition to saving of adsorbent materials, the superior process efficacy enables implementation of more compact water and wastewater treatment devices with smaller footprints, particularly for decentralized applications and point-of-use systems. Current research activities mainly focus on the following types of nanoadsorbents:

- carbon-based nanoadsorbents ie, carbon nanotubes (CNTs)

- metal-based nanoadsorbents

Table I Overview of types of nanomaterials applied for water and wastewater technologies

\begin{tabular}{lll}
\hline Nanomaterial & Properties & Applications \\
\hline Nanoadsorbents & + high specific surface, higher adsorption & Point-of-use, removal of \\
organics, heavy metals, bacteria & & \\
rates, small footprint & high production costs & Removal of heavy metals \\
nanometals and & compressible, abrasion-resistant, magnetic & (arsenic) and radionuclides, \\
& + photocatalytic $\left(\mathrm{WO}_{3}, \mathrm{TiO}_{2}\right)$ & media filters, slurry reactors, \\
Membranes and & - less reusable & - reliable, largely automated process \\
membrane processes & - relative high energy demand & All fields of water and waste-
\end{tabular}


- polymeric nanoadsorbents

- zeolites.

\section{Carbon nanotubes}

CNTs are allotropes of carbon with a cylindrical nanostructure. Depending on their manufacturing process, CNTs are categorized as single-walled nanotubes and multiwalled nanotubes, respectively. Besides having a high specific surface area, CNTs possess highly assessable adsorption sites and an adjustable surface chemistry. Due to their hydrophobic surface, CNTs have to be stabilized in aqueous suspension in order to avoid aggregation that reduces the active surface. They can be used for adsorption of persistent contaminants as well as to preconcentrate and detect contaminants. ${ }^{5}$ Metal ions are adsorbable by CNTs through electrostatic attraction and chemical bonding. ${ }^{6}$

Furthermore, CNTs exhibit antimicrobial properties by causing oxidative stress in bacteria and destroying the cell membranes. Although chemical oxidation occurs, no toxic byproducts are produced, which is an important advantage over conventional disinfection processes like chlorination and ozonation. ${ }^{7}$ They can be simply regenerated through appropriate adjustments of operating conditions, like $\mathrm{pH}$ shift.

Conventional desalination methods are energy-consuming and technically demanding, whereas adsorption-based techniques are simple and easy to use for point-of-use water purification devices, yet their capacity to remove salts is limited. Yan et a ${ }^{8}$ developed plasma-modified ultralong CNTs that feature an ultrahigh specific adsorption capacity for salt (exceeding $400 \%$ by weight) that is two orders of magnitude higher when compared with conventional carbon-based water treatment systems. These ultralong CNTs can be implemented in multifunctional membranes that are able to remove not only salt but also organic and metal contaminants. Nextgeneration potable water purification devices equipped with these novel CNTs are expected to have superior desalination, disinfection, and filtration properties.

Recently, a team of US researchers developed a sponge made of pure CNTs with a dash of boron that shows a remarkable ability to absorb oil from water. The oil can be stored in the sponge for later retrieval or burned off so the sponge can be reused. If they succeed in generating large sheets or find a way to weld the sheets, the sponge material can be applied in removing oil spills for oil remediation. ${ }^{9}$

Although CNTs have significant advantages over activated carbon, their use on an industrial scale for large municipal water and wastewater treatment plants is not expected in the midterm because of high production costs..$^{10}$ Point-of-use applications that require small quantities of CNTs are more competitive; for example, for the elimination of heavily degradable contaminants such as many antibiotics and pharmaceuticals. ${ }^{11-13}$

\section{Polymeric nanoadsorbents}

Polymeric nanoadsorbents such as dendrimers (repetitively branched molecules) are utilizable for removing organics and heavy metals. Organic compounds can be adsorbed by the interior hydrophobic shells, whereas heavy metals can be adsorbed by the tailored exterior branches. ${ }^{14}$ Diallo et al ${ }^{15}$ integrated dendrimers in an ultrafiltration device in order to remove copper from water. Nearly all copper ions were recovered by use of this combined dendrimer-ultrafiltration system. The adsorbent is regenerated simply through a $\mathrm{pH}$ shift. However, due to the complex multistage synthesis of dendrimers, up until now there are no commercial suppliers, except for some recently founded companies in the People's Republic of China.

Sadeghi-Kiakhani et al ${ }^{16}$ produced a highly efficient bioadsorbent for the removal of anionic compounds such as dye from textile wastewater by preparing a combined chitosandendrimer nanostructure. The bioadsorbent is biodegradable,

Table 2 Properties, applications, and innovative approaches of nanoadsorbents

\begin{tabular}{|c|c|c|c|c|}
\hline \multirow[t]{2}{*}{ Nanoadsorbents } & \multicolumn{2}{|l|}{ Properties } & \multirow[t]{2}{*}{ Applications } & \multirow[t]{2}{*}{ Novel approaches } \\
\hline & Positive & Negative & & \\
\hline Carbon nanotubes & $\begin{array}{l}\text { Highly assessable sorption sides, } \\
\text { bactericidal, reusable }\end{array}$ & $\begin{array}{l}\text { High production costs, } \\
\text { possibly health risk }\end{array}$ & $\begin{array}{l}\text { Point-of-use, heavily } \\
\text { degradable contaminants } \\
\text { (pharmaceuticals, antibiotics) }\end{array}$ & $\begin{array}{l}\text { Ultralong carbon nanotubes } \\
\text { with extremely high specific salt } \\
\text { adsorption }\end{array}$ \\
\hline $\begin{array}{l}\text { Polymeric } \\
\text { nanoadsorbents } \\
\text { (dendrimers) }\end{array}$ & $\begin{array}{l}\text { Bifunctional (inner shell adsorbs } \\
\text { organics, outer branches adsorb } \\
\text { heavy metals), reusable }\end{array}$ & $\begin{array}{l}\text { Complex multistage } \\
\text { production process }\end{array}$ & $\begin{array}{l}\text { Removal of organics and } \\
\text { heavy metals }\end{array}$ & $\begin{array}{l}\text { Biodegradable, biocompatible, } \\
\text { nontoxic bioadsorbent (combination } \\
\text { of chitosan and dendrites) }\end{array}$ \\
\hline Zeolites & $\begin{array}{l}\text { Controlled release of } \\
\text { nanosilver, bactericidal }\end{array}$ & $\begin{array}{l}\text { Reduced active surface } \\
\text { through immobilization } \\
\text { of nanosilver particles }\end{array}$ & Disinfection processes & $\begin{array}{l}\text { Nanozeolites by laser induced } \\
\text { fragmentation }\end{array}$ \\
\hline
\end{tabular}


biocompatible, and nontoxic. They achieve removal rates of certain dyes up to $99 \%$.

\section{Zeolites}

Zeolites in combination with silver atoms have been known since the early 1980 s. ${ }^{17}$ Zeolite has a very porous structure in which nanoparticles such as silver ions can be embedded. There they are released from the zeolite matrix by exchange with other cations in solution. Egger et $\mathrm{a}^{18}$ compared various materials containing nanosilver, including zeolites. When used for sanitary purposes, the silver attacks microbes and inhibits their growth, as shown by Agion ${ }^{\circledR}$ (Sciessent LLC, Wakefield, MA, USA). ${ }^{19}$ A small amount of silver ions is released from the metallic surface when placed in contact with liquids. The success of this composition in water disinfection was shown once again by Petrik et al. ${ }^{20}$ The Water Research Commission Report No KV 297/12 shows the innovative use of zeolites as an adsorbing platform for silver nanoparticles as a source of silver ions for a disinfectant. Another possibility is applying zeolites themselves as nanoparticles, as shown by Tiwari et al, who prepared nanozeolites by laser-induced fragmentation of zeolite Linde type A microparticles and Jung et al, who used nanozeolites in sequencing batch reactors for waste water treatment. ${ }^{21,22}$ For example, the Agion product line includes a compound made from zeolites and naturally occurring silver ions that exhibits antibacterial properties. Table 2 summarizes the most important properties, applications, and innovative approaches of nanoadsorbents.

Both CNTs and nanometals (see section on Nanometals and nanometal oxides) are highly effective nanoadsorbents for the removal of heavy metals such as arsenic. With regard to this application field, nanometals and zeolites benefit from their cost-effectiveness and compatibility with existing water treatment systems since they can be implemented in pellets and beads for fixed absorbers. In contrast, the production of CNTs is very costly, and additional technical devices, for example, membrane filtration plants, have to be integrated in order to make absolutely sure that no nanoparticles are discharged into the aqueous environment. A major advantage of CNTs in terms of micropollutant removal is their strong adsorption capacity for polar organic compounds due to the diverse interactions between contaminants and CNTs. Given that up until now CNTs have not been cost-competitive when compared with broad-spectrum adsorbents like activated carbon, future applications will focus on highly specific adsorption processes, where only small quantities of CNTs are required, or on novel applications where CNT is the only suitable adsorbent.
Whereas CNTs and nanometals are commercially available for diverse applications, market entry of polymeric nanoadsorbents is ongoing. From the point of view of process efficacy, polymeric nanoadsorbents are highly advanced materials allowing both removal of heavy metals as well as organic contaminants within one process step. The major limitation of this novel adsorption technology is the technically demanding and cost-intensive production process for polymeric dendrimers that has to be improved.

In terms of ecotoxicity, the nanometals, CNTs, and zeolites described here consist of very well characterized basic materials that occur naturally in the environment and are classified as nontoxic. Thus, the potential toxic effect mainly depends on the size and shape of the respective nanoadsorbents, as well as chemical stabilizers and surface modifications. The ecotoxicity has to be re-evaluated for each new modification of a known nanomaterial, so a general assessment of nanoadsorbents in terms of their toxicity potential cannot be given.

\section{Nanometals and nanometal oxides}

Nanoscale metal oxides are promising alternatives to activated carbon and effective adsorbents to remove heavy metals and radionuclides. As well as having a high specific surface area, they feature a short intraparticle diffusion distance and are compressible without a significant reduction of surface area. Some of these nanoscale metal oxides (eg, nanomaghemite and nanomagnetite) are superparamagnetic, which facilitates separation and recovery by a lowgradient magnetic field. They can be employed for adsorptive media filters and slurry reactors. ${ }^{13}$ Nano iron hydroxide $[\alpha-\mathrm{FeO}(\mathrm{OH})]$ is a robust abrasion-resistant adsorbent with a huge specific surface area that enables adsorption of arsenic from waste and drinking water. ${ }^{23}$ ArsenXnp (SolmeteX Inc., Philadelphia, PA, USA) is a commercially available hybrid ion exchange medium comprising iron oxide nanoparticles and polymers and is highly efficient in removing arsenic and requires little back wash. Usually, nanometals and nanometal oxides are compressed into porous pellets or used in powders for industrial use.

\section{Nanosilver and nano-titanium dioxide}

Nanosilver has been used in the photo development process since the late $1800 \mathrm{~s}$, and has been registered with the Environmental Protection Agency for use in swimming pool algaecides since 1954 and drinking water filters since the 1970s. Although nanosilver exhibits a strong and 
broad-spectrum antimicrobial activity, it has hardly any harmful effects in humans. It is already applied to point-ofuse water disinfection systems and antibiofouling surfaces. ${ }^{24}$ Nano-titanium dioxide $\left(\mathrm{TiO}_{2}\right)$, featuring high chemical stability and low human toxicity at a cheap price, is utilizable in disinfection and decontamination processes. ${ }^{25,26}$ Further information is provided in the section on photocatalysis. The main advantage of nano- $\mathrm{TiO}_{2}$ over nanosilver is the nearly endless life time of such coatings, since $\mathrm{TiO}_{2}$ as a catalyst remains unchanged during the degradation process of organic compounds and micro-organisms. The antimicrobial effect of nanosilver is based on the continuous release of silver ions. After a certain operation period, depending on the thickness and composition of the nanosilver layers, the coating has to be renewed or the complete device, including the bulk material, has to be disposed of, leading to significant replacement costs. However, compared with $\mathrm{TiO}_{2}$, which needs energyconsuming ultraviolet lamps for activation, nanosilver kills bacteria with no need of additional energy-consuming devices. That makes nanosilver a favorable disinfectant for remote areas. ${ }^{27}$

A disadvantage of bactericidal nanoparticles in general except for nano- $\mathrm{TiO}_{2}$ is that no bactericidal substances such as hydroxyl radicals remain in the water past the contact time that could ensure the water quality in storage and distribution devices (depot effect).

\section{Magnetic nanoparticles}

The use of magnetic nanoparticles (magnetite $\mathrm{Fe}_{3} \mathrm{O}_{4}$ ) for separation of water pollutants has already been established in ground water remediation, in particular for the removal of arsenic. ${ }^{28}$ The conventionally applied "pump-and-treat" technology for groundwater treatment comprises pumping up the groundwater to the surface and further treatment, usually by activated carbon for final purification. The considerably extended operating hours and higher environmental clean-up costs can be reduced by applying in situ technologies.
Magnetic nanoparticles can be injected directly into the contaminated ground, and loaded particles can be removed simply through a magnetic field. ${ }^{22}$ Besides ground water remediation, magnetic recovery makes such nanoparticles an ideal compound to increase the osmotic pressure of draw solutions used in forward osmosis. Forward osmosis as contrary process to reverse osmosis draws water from a low osmotic pressure to one with a higher osmotic pressure (draw solution) using the osmotic gradient. ${ }^{29}$

Since magnetic nanoparticles have been established in medical applications for some time, and are approved by the US Food and Drug Administration as a contrast agent for magnetic resonance imaging, comprehensive in vitro/in vivo toxicity studies have already been carried out. Thus, an extensive database for the toxicity of magnetic nanoparticles is provided that helps to develop and apply magnetic nanoparticles with minimal toxicity for water and wastewater processes. Another benefit of magnetic nanoparticles in terms of the removal and fate of nanoparticles in an aqueous environment is the fact that they can be simply recovered by applying a magnetic field.

\section{Nano-zero valent iron}

As an alternative, nano-zero valent iron can be used for remediation of groundwater contaminated with chlorinated hydrocarbon fluids and perchlorates. A suspension of nanozero valent iron can be injected into the groundwater, allowing in situ treatment of the ground water. On the one hand, due to its high specific surface, nano-zero valent iron is much more reactive in comparison with conventional granular iron; on the other, as a result of its high reactivity, the life time of nano-zero valent iron is very low, so that further research work, for example, on surface modifications, is necessary for stabilization of these nanoparticles. ${ }^{23,30,31}$

Table 3 summarizes the most important properties, applications, and innovative approaches involving nanometals and nanometal oxides. Whether in the midterm nanometals and nanometal oxides will be widely established in the water

Table 3 Properties, applications, and innovative approaches for nanometals and nanometal oxides

\begin{tabular}{|c|c|c|c|c|}
\hline \multirow{2}{*}{$\begin{array}{l}\text { Nanometals and } \\
\text { nanometal oxides }\end{array}$} & \multicolumn{2}{|l|}{ Properties } & \multirow[t]{2}{*}{ Applications } & \multirow[t]{2}{*}{ Novel approaches } \\
\hline & Positive & Negative & & \\
\hline $\begin{array}{l}\text { Nanosilver and } \\
\text { nano- } \mathrm{TiO}_{2}\end{array}$ & $\begin{array}{l}\text { Bactericidal, low human } \\
\text { toxicity } \\
\text { Nano-TiO, }_{2} \text { high chemical } \\
\text { stability, very long life time }\end{array}$ & $\begin{array}{l}\text { Nanosilver, limited } \\
\text { durability } \\
{\text { Nano- } \mathrm{TiO}_{2} \text {, requires }}_{\text {ultraviolet activation }}\end{array}$ & $\begin{array}{l}\text { Point-of-use water disinfection, } \\
\text { antibiofouling surfaces, } \\
\text { decontamination of organic } \\
\text { compounds, remote areas }\end{array}$ & $\begin{array}{l}\mathrm{TiO}_{2} \text { modification for } \\
\text { activation by visible } \\
\text { light, } \mathrm{TiO}_{2} \text { nanotubes }\end{array}$ \\
\hline Magnetic nanoparticles & $\begin{array}{l}\text { Simple recovery } \\
\text { by magnetic field }\end{array}$ & Stabilization is required & Groundwater remediation & Forward osmosis \\
\hline $\begin{array}{l}\text { Nano zero-valent } \\
\text { iron }\end{array}$ & Highly reactive & $\begin{array}{l}\text { Stabilization is required } \\
\text { (surface modification) }\end{array}$ & $\begin{array}{l}\text { Groundwater remediation (chlorinated } \\
\text { hydrocarbon, perchlorates) }\end{array}$ & $\begin{array}{l}\text { Entrapment in polymeric } \\
\text { matrices for stabilization }\end{array}$ \\
\hline
\end{tabular}


and wastewater sector strongly depends on the efficiency (nano- $\mathrm{TiO}_{2}$ ) and stability of the metals (magnetic nanoparticles, nano zero-valent iron, nanosilver).

Photocatalytic $\mathrm{TiO}_{2}$ benefits from its low price, high availability, inertness, and broad-spectrum effect on the chemical degradation of the majority of organic contaminants and micro-organisms. This makes it an ideal, robust, durable, and effective nanomaterial for chemical-free water and wastewater treatment processes in both large-scale and small-scale treatment plants. However, up until now, the efficacy of ultraviolet-visible photocatalytic $\mathrm{TiO}_{2}$ in particular has been relatively low compared with similar oxidation processes like ozonation. Nanosilver benefits from its low toxicity, high availability, and well proven bactericidal effect. However, since it is dissolved during the duration of the process, its application is restricted to low feed volumes where a maximum life time can be achieved, for example, with point-of-use devices.

If highly effective nano- $\mathrm{TiO}_{2}$ able to be activated by visible light can be developed successfully, photocatalysis will become one of the most promising water and wastewater treatment technologies due to its flexible and manifold implementation and easy scalability.

Due to their magnetic recoverability, magnetic nanoparticles seem to be advantageous over nano-zero valent iron in the field of ground water remediation. In addition to the toxicity potential of the nanometal oxides described here that is quite low (see section on Harmful effects on aquatic organisms), the additional potential effect of the required stabilizer on the aqueous environment also has to be taken into consideration.

\section{Membranes and membrane processes}

Membrane separation processes are rapidly advancing applications for water and wastewater treatment. Membranes provide a physical barrier for substances depending on their pore size and molecule size. Membrane technology is well established in the water and wastewater area as a reliable and largely automated process. Novel research activities with regard to nanotechnology focus on improving selectivity and flux efficiency, eg, by developing antifouling layers. The following sections describe the state of the art in the field of nanoengineered membrane filtration.

\section{Nanofiltration membranes}

Nanofiltration is one of the membrane filtration techniques and can be defined as a pressure-driven process wherein molecules and particles less than $0.5 \mathrm{~nm}$ to $1 \mathrm{~nm}$ are rejected by the membrane. Nanofiltration membranes are characterized by a unique charge-based repulsion mechanism allowing the separation of various ions. ${ }^{13,32,33}$ They are mostly applied for the reduction of hardness, color, odor, and heavy metal ions from groundwater. The conversion of sea water into potable water (desalination) is another prosperous field of application since comparable desalination technologies are very cost-intensive.

\section{Nanocomposite membranes}

Nanocomposite membranes can be considered as a new group of filtration materials comprising mixed matrix membranes and surface-functionalized membranes. Mixed matrix membranes use nanofillers, which are added in a matrix material. In most cases, the nanofillers are inorganic and embedded in a polymeric or inorganic oxide matrix. These nanofillers feature a larger specific surface area leading to a higher surface-tomass ratio. ${ }^{34,35}$ Metal oxide nanoparticles $\left(\mathrm{Al}_{2} \mathrm{O}_{3}, \mathrm{TiO}_{2}\right)$ can help to increase the mechanical and thermal stability as well as permeate flux of polymeric membranes. The incorporation of zeolites improves the hydrophilicity of membranes resulting in raised water permeability. Antimicrobial nanoparticles (nanosilver, CNTs) and (photo)catalytic nanomaterials (bimetallic nanoparticles, $\mathrm{TiO}_{2}$ ) are mainly used to increase resistance to fouling.

Kim and Deng ${ }^{36}$ developed a new type of thin film nanocomposite membrane by adding ordered mesoporous carbons as nanofillers into thin film polymeric matrices. Thin film nanocomposite membranes are semipermeable membranes with a selective layer on the upper surface that is usually applied to reverse osmosis. The surface of the hydrophobic ordered mesoporous carbons is treated by applying atmospheric pressure plasma to achieve hydrophilized ordered mesoporous carbons with higher solubility. Only a small percentage of hydrophilized ordered mesoporous carbons (adding nanomaterial) is required to raise the hydrophilicity of the membrane surface, resulting in considerably increased pure water permeability. Similar results have been obtained using a thin film nanocomposite membrane of polyamide and nano-NaX zeolite $(40-150 \mathrm{~nm})$ coated by interfacial polymerization of trimesoyl chloride and m-phenylenediamine monomers over porous polyethersulfone. ${ }^{37}$

The company $\mathrm{NanoH}_{2} \mathrm{O}$, (Los Angeles, CA, USA) developed and introduced the QuantumFlux membrane to the market for liquid application (reverse osmosis), which can be classified as a mixed matrix membrane (WO 2006/098872 A3). This membrane was generated by adding superhydrophilic nanoparticles to a polyamide thin film to form a thin film 
nanocomposite membrane with higher permeate efficiency and lower fouling potential. The nanoparticles are designed to attract water and are highly porous, soaking up water like a sponge while repelling dissolved salts and other impurities. The hydrophilic nanoparticles embedded in the membrane also repel organic compounds and bacteria, which tend to clog up conventional membranes over time.

Another method used to prevent membrane clogging might be surface functionalization with chemical substances capable of oxidizing organic contaminants and thus prevent building up of fouling layers. Specially designed coatings, such as nanosilver and $\mathrm{TiO}_{2}$ layers, prevent fouling of membranes or heat exchangers and/or exhibit a decontamination effect on organic pollutants. Due to their low thickness, such nanoscale functional surface layers require few materials and maintain the surface profile of the bulk material while at the same time immobilizing potentially harmful nanoparticles.

Gehrke et al ${ }^{38}$ deposited photocatalytic $\mathrm{TiO}_{2}$ nanoparticles (P25, Evonik) on a metallic filter material (microsieve) by a dip coating process. The fouling repellent and photocatalytic nanocoatings degrade the water impurities close to the microsieve surface before a dense cake layer is formed. However, this kind of surface activation is restricted to chemically robust materials, excluding polymeric membranes that would be degraded by the induced oxidation process.

A very novel research approach focuses on bionanocomposite membranes with highly selective proteins immobilized on their surfaces. ${ }^{39} \mathrm{~A}$ thin film of S-layer proteins is applied on a metallic microsieve by a layer-to-layer process, with a high selectivity for platinum group elements and certain rare earth metals. The so-called S-sieve has an enormous potential for the recycling of strategic metals, even when the indented metals are very weakly concentrated.

\section{Self-assembling membranes}

Some research activity is aiming to nanostructure new membrane materials, especially for gas permeation, by means of self-assembly of block copolymers (block copolymer membranes). Self-assembly is defined as the "autonomous organization of components into patterns or structures without human intervention". ${ }^{40}$ The structure of these membranes can be systematically controlled by the process parameters, so that the targeted membranes feature specific tailor-made characteristics (eg, homogeneous nanopores). High-density cylindrical nanopores can be formed that way to be useful not only for micro/nanofluidic devices but also for water filtration. ${ }^{41}$ Such membranes belonging to the category of ultrafiltration provide enhanced selectivity and permeate efficiency. However, due to difficulties with adaption of the techniques to large-scale membrane areas, up until now selfassembling membranes have only been produced in small quantities in the laboratory. ${ }^{42}$

\section{Nanofiber membranes}

Electrospinning produces fibers by drawing very fine different materials like polymers or ceramics into an electric field. ${ }^{43}$ These so-called nanofibers are in the range of nanometers and are often used in separation and filtration processes. The technical process ensures a high specific surface porosity ${ }^{13}$ and thus a high surface to mass ratio. Another benefit of nanofibers is their capacity to be tailored to specifics such as membrane thickness and an interconnected open pore structure ${ }^{34}$ The electrospinning process is a fully developed technology in air treatment, but nearly unknown in water and wastewater treatment. Therefore, it involves a very high research potential. ${ }^{44}$

One already patented nanofiber filter is NanoCeram ${ }^{\circledR}$ (Argonide Corporation, Sanford, FL, USA), an electropositive filter medium that is implemented in a filter cartridge. NanoCeram is a small diameter fiber, with a high surface area $\left(300-600 \mathrm{~m}^{2} / \mathrm{g}\right)$, that can be produced in kilogram quantities by a proprietary sol gel reaction. The product is a white, free-flowing powder consisting of fibers approximately $2 \mathrm{~nm}$ in diameter and tens to hundreds of nanometers in length that collects in aggregates. Embedded into glass and cellulose nonwoven sheets, a filtration material is created that is comparable with ultrafiltration but has higher flow rates that attract dirt, bacteria, viruses, and proteins using an electrostatic effect. NanoCeram can be applied in a prefiltration mode for ultrapure water systems, to produce laboratory or process water, in commercial/industrial water treatment, as a microbiological sampler, or as a stand-alone filtration device. ${ }^{45}$

Feng et $\mathrm{a}^{35}$ demonstrated the effect of electrospinning and thermal treatment in a solution of thermoplastic fluorocarbon and silicates, whereby 10,20 , and $40 \mathrm{wt} \%$ of tetramethyl orthosilicate were used in polyvinylidene fluoride to enhance the membrane parameters. Thermal treatment of these composite membranes is expected to result in enormous enhancement of their mechanical properties and hydrophobicity by increasing the mass fraction of tetramethyl orthosilicate in polyvinylidene fluoride. Thus, membranes made of these hydrophobic nanofiber materials might become very applicable for separation of organic solvents, leading to higher flux efficiency. 
In contrast with nano- $\mathrm{TiO}_{2}$ and nanosilver, that want to prevent from surface fouling some further research activities aim at the controlled immobilization of biofilms on the surface of nanofibers in order to degrade drugs such as antibiotics. The main advantage of nanofiber materials according to biofilm immobilization is their comparability with the dimensions of micro-organisms, the surface morphology, and biocompatibility. The micro-organisms benefit from protection against shear forces and the toxic effects of the surrounding environment. Thus, bionanofibers are ideal substrates for formation of microbial biofilms, resulting in accelerated biodegradation due to a higher rate of carrier ingrowth. Common nanofibers are made of polymers like polyurethane, polylactic acid, and polyethylene oxide..$^{33}$

\section{Aquaporin-based membranes}

Aquaporins are pore-forming proteins and ubiquitous in living cells. Under certain conditions, they form highly selective water channels that are able to reject most ionic molecules. The combination of high water permeability and selective rejection make them an ideal material for creating novel high flux biomimetic membranes. To stabilize the aquaporins, they are incorporated in vesicles. Since stand-alone membranes based on these vesicles are too mechanically weak for their intended technical applications, like osmosis, they are embedded in a polymeric matrix or deposited onto polymeric substrates such as nanofiltration membranes. ${ }^{46}$ Aquaporin Inside $^{\mathrm{TM}}$ (Aquaporin A/S, Copenhagen, Denmark) is the first commercially available biomimetic membrane with aquaporins embedded. This kind of membrane is able to withstand pressures up to 10 bar and allow a water flux $>100 \mathrm{~L} /\left(\mathrm{hm}^{2}\right)$ for example required for brackish water desalination.
Xie et $a l^{47}$ reconstituted aquaporins into self-assembled polymer vesicles and used in situ "surface imprinting" polymerization to generate a dense hydrophobic polymer layer. This novel membrane possesses a well-controlled nanostructured selective layer and as high mechanical strength as necessary to withstand pressure-driven water filtration processes.

In order to enter the water and wastewater market, aquaporin-based membranes have to be competitive with conventional membranes in terms of stability and useful life. Currently, there exists no such membrane that can permanently withstand the operating pressures of reverse osmosis, the harsh cleaning conditions (high temperature, acidic and alkaline cleaners), and fouling-based corrosion. Table 4 summarizes the most important properties, applications, and innovative approaches for membranes and membrane processes according to nanotechnology and water and wastewater treatment processes.

\section{Photocatalysis}

Photocatalysis is an advanced oxidation process that is employed in the field of water and wastewater treatment, in particular for oxidative elimination of micropollutants and microbial pathogens. ${ }^{48,49}$ As reported in the literature, ${ }^{50-52}$ most organic pollutants can be degraded by heterogeneous photocatalysis. Due to its high availability, low toxicity, cost efficiency, and well known material properties, $\mathrm{TiO}_{2}$ is widely utilized as a photocatalyst. ${ }^{13}$ When $\mathrm{TiO}_{2}$ is irradiated by ultraviolet light with an appropriate wavelength in the range of 200-400 nm, electrons will be photoexcited and move into the conduction band. As a result of photonic excitation, electron-hole pairs are created, leading to a complex chain

Table 4 Properties, applications, and innovative approaches for nanomembranes

\begin{tabular}{|c|c|c|c|c|}
\hline \multirow[t]{2}{*}{ Nanomembranes } & \multicolumn{2}{|l|}{ Properties } & \multirow[t]{2}{*}{ Applications } & \multirow[t]{2}{*}{ Novel approaches } \\
\hline & Positive & Negative & & \\
\hline $\begin{array}{l}\text { Nanofiltration } \\
\text { membranes }\end{array}$ & $\begin{array}{l}\text { Charge-based repulsion, relative } \\
\text { low pressure, high selectivity }\end{array}$ & $\begin{array}{l}\text { Membrane blocking } \\
\text { (concentration polarization) }\end{array}$ & $\begin{array}{l}\text { Reduction of hardness, color, } \\
\text { odor, heavy metals }\end{array}$ & Sea water desalination \\
\hline $\begin{array}{l}\text { Nanocomposite } \\
\text { membranes }\end{array}$ & $\begin{array}{l}\text { Increased hydrophilicity, water } \\
\text { permeability, fouling resistance } \\
\text { and thermal/mechanical } \\
\text { robustness }\end{array}$ & $\begin{array}{l}\text { Resistant bulk material } \\
\text { required when using oxidizing } \\
\text { nanomaterial, possibly release } \\
\text { of nanoparticles }\end{array}$ & $\begin{array}{l}\text { Highly dependent on type of } \\
\text { composite, eg, reverse osmosis, } \\
\text { removal of micropollutants }\end{array}$ & $\begin{array}{l}\text { Bionanocomposite } \\
\text { membranes }\end{array}$ \\
\hline $\begin{array}{l}\text { Self-assembling } \\
\text { membranes }\end{array}$ & $\begin{array}{l}\text { Homogeneous nanopores, } \\
\text { tailor-made membranes }\end{array}$ & $\begin{array}{l}\text { Small quantities available } \\
\text { (laboratory scale) }\end{array}$ & Ultrafiltration & Process scale up \\
\hline $\begin{array}{l}\text { Nanofiber } \\
\text { membranes }\end{array}$ & $\begin{array}{l}\text { High porosity, tailor-made, } \\
\text { higher permeate efficiency, } \\
\text { bactericidal }\end{array}$ & $\begin{array}{l}\text { Pore blocking, possibly } \\
\text { release of nanofibers }\end{array}$ & $\begin{array}{l}\text { Filter cartridge, ultrafiltration, } \\
\text { prefiltration, water treatment, } \\
\text { stand-alone filtration device }\end{array}$ & $\begin{array}{l}\text { Composite nanofiber } \\
\text { membranes, bionanofiber } \\
\text { membranes }\end{array}$ \\
\hline $\begin{array}{l}\text { Aquaporin-based } \\
\text { membranes }\end{array}$ & $\begin{array}{l}\text { High ionic selectivity and } \\
\text { permeability }\end{array}$ & Mechanical weakness & Low pressure desalination & $\begin{array}{l}\text { Stabilization processes } \\
\text { (surface imprinting, } \\
\text { embedding in polymers) }\end{array}$ \\
\hline
\end{tabular}


of oxidative-reductive reactions. Hence, the biodegradability of heavily decomposable substances can be increased in a pretreatment step. Principally, persistent compounds like antibiotics or other micropollutants can be photocatalytically eliminated in polishing processes, such as tertiary clarification steps in municipal wastewater treatment plants. However, as the ultraviolet A radiation is only about $5 \%$ that of sunlight, the photon efficiency is quite low, limiting use on an industrial scale.

Activation of $\mathrm{TiO}_{2}$ is usually induced by an ultraviolet lamp, but sunlight in addition to artificial light sources is also permitted. KRONOClean 7000 (Kronos Inc., Cranbury, NJ, USA) is a novel photocatalyst where the bandgap is shifted to a lower energy, enabling use of a broader spectrum of sunlight. Besides $\mathrm{TiO}_{2}$, tungsten trioxide, and some fullerene derivatives such as Fullerol and $\mathrm{C}_{60}$ encapsulated with poly(N-vinylpyrrolidone) as well as composites with $\mathrm{TiO}_{2}$ have an photocatalytic effect under visible light irradiation. ${ }^{53,54}$ However, they are producing ${ }^{1} \mathrm{O}_{2}$ that has a lower oxidation potential than $\mathrm{TiO}_{2}$ and the price is rarely high. Further approaches to enhance the performance of $\mathrm{TiO}_{2}$ nanoparticles include creation of $25 \%-40 \%$ more efficient $\mathrm{TiO}_{2}$ nanotubes and doping with noble metals, reducing the $\mathrm{e}^{-} / \mathrm{h}^{+}$recombination. ${ }^{55}$

In recent years, many research groups have investigated the combination of separation and catalytic processes (using a membrane photocatalytic reactor) in order to both purify the water and retain the catalytic particles. ${ }^{56-58}$ When using highly efficient nanoparticles, an appropriate filtration system like nanofiltration has to be implemented in order to ensure complete rejection of possibly harmful nanoparticles. Thus, an extensive and relatively costly installation technology is necessary, including high pressure pumps.

A solution for rejection of photocatalytic nanoparticles is their immobilization on defined materials by use of suitable coating processes, such as physical or chemical vapor deposition, as well as wet chemical coating processes. When using a microfilter material as a substrate, a beneficial multibarrier effect comprising mechanical filtration and chemical decontamination is obtained (Figure 1). Dirt particles and larger microorganisms are rejected by microfiltration membranes at the same time that viruses, spores, and contaminants are chemically eliminated and degraded.

For example, Gehrke et $\mathrm{al}^{38}$ deposited photocatalytic $\mathrm{TiO}_{2}$ nanoparticles alone or in combination with bactericidal silver on the surface of metallic filters. They used dip coating as well as chemical and physical vapor deposition for producing photocatalytic thin coatings with a maximum thickness of
$500 \mathrm{~nm}$. However, due to the reduced reactive surface of the photocatalyst when compared with nanoparticle suspensions, the photocatalytic activity decreases by at least one order of magnitude. ${ }^{58}$

In recent years, some advanced oxidation processes were successfully introduced to the water technology market. For example, Purific Water (Holiday, FL, USA) established a combined water treatment process comprising photocatalysis and ceramic membrane filtration, with a capacity of more than 4 million cubic meters per day in particular for the degradation of volatile organic compounds and 1.4 dioxine for groundwater remediation. ${ }^{59}$

\section{Limitations of nanobased materials and processes for water applications}

Commercialization of nanoengineered materials for water and wastewater technology strongly depends on their impact on the aqueous environment. Numerous studies including toxicity tests, life cycle analysis, technology assessment, and pathways and dispersal of nanoparticles in water bodies have been carried out in order to evaluate the health risks of nanomaterials (see section on Potential ecotoxicity risks of nanobased materials and processes related to water applications). The results of these studies have led to a better understanding of the behavior of nanoparticles such as $\mathrm{CNTs}_{2}, \mathrm{TiO}_{2}$, and silver nanoparticles in aqueous systems; thus, stakeholders from administration, politics, and industry are supported to create new laws and regulations or modify present ones. However, many studies have yielded contradictory results, since no general standards and conditions for experimental tests and measurements have been determined, which slows down the necessary decision processes.

\section{Legal background of nanobased materials and processes related to water applications}

On the one hand, the enabling nanotechnology is promoted as one of the most challenging key technologies of this century. Billions of dollars have been spent on research framework programs intended to promote nanotechnology and to bring novel materials and processes to market. For example, the 2015 federal budget has allocated more than 1.5 billion US dollars ${ }^{60}$ to the National Nanotechnology Initiative (Arlington, VA, USA), that has nanotechnologyrelated activities ongoing in 20 departments and independent agencies. Horizon 2020, the research framework program in the European Union, provides US\$110 billion over a period of 7 years for research and innovation projects, including 


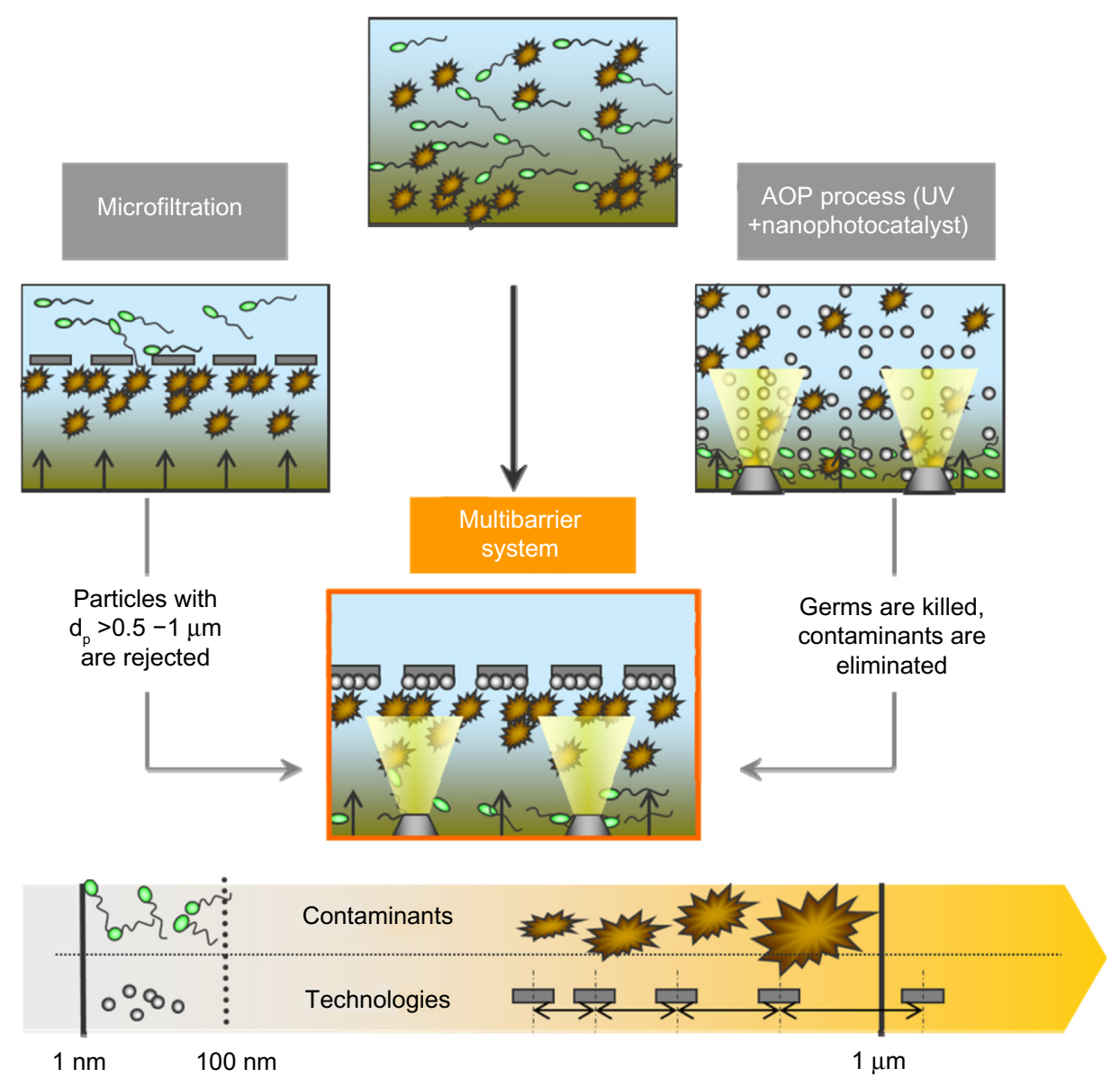

Figure I Multibarrier effect of photocatalytic titanium dioxide particles in combination with microfiltration. Abbreviations: AOP, advanced oxidation process; UV, ultraviolet.

US\$92 million for water innovations and US\$686 million for nanotechnology in $2014 .{ }^{61,62}$ In order to combine water and nanotechnology, there are joint calls for "low-energy solutions for drinking water production" that involve implementation of novel nanoengineered materials and processes for water applications.

On the other hand, steps have to be taken to prevent any environmental damage, including to aqueous organisms, plants, and human beings, when nanomaterials are applied. Thus, various laws and regulations are in progress on an international level and still have to be incorporated in valid national laws. Since every country has its own complex laws and guidelines, the following gives only a rough overview of the way the European Union and the USA deal with implementation of novel regulations pertaining to nanomaterials and their exposure in water bodies. The most important general problem with all legal approaches results from the inability to assign nanomaterials with their crossover functions to an individual legal framework.
In Europe, nanomaterials are regulated by $\mathrm{REACH}^{63}$ (Registration, Evaluation, Authorization and Restriction of Chemicals) because they are covered by the REACH definition of a chemical "substance". REACH is a European Union program that regulates production and use of chemical substances and their potential impact on both human health and the environment. The general obligations of REACH therefore apply, as for any other substance, and do not explicitly stipulate nanomaterials. However, certain EU member states have concerns, mainly about REACH tonnage thresholds, market surveillance and registries, and the time required for access to information about nanomaterials on the market. Several nongovernmental organizations claim to have integrated the EU definition of nanomaterials ${ }^{64}$ into all relevant current regulations.

The European Water Framework Directive, ${ }^{65}$ which established a framework for the protection of inland surface waters, transitional waters, coastal waters, and groundwater, refers to REACH for evaluation of priority substances. Due 
to their close connection, any amendment of REACH related to nanomaterials is automatically implemented in the water directive.

In the USA, the Environmental Protection Agency has permitted limited manufacture of new nanoscale chemical materials through use of administrative orders or significant new use rules under the Toxic Substances Control Act. The developing of corresponding significant new use rules started in 2010 and these are being continually expanded. The agency has also allowed the manufacture of new nanoscale chemical materials under the terms of certain regulatory exemptions, but only in circumstances with severely controlled exposures to protect against unreasonable risk. Use of nanomaterials in combination with the medium of water is not explicitly mentioned. ${ }^{66}$

Although every country that produces and/or uses nanomaterials is aware of their potential risks, no specific regulation for nanomaterials has been implemented in the respective laws so far. This mainly accounts for the relatively vague regulations originating from pioneer countries, such as Canada, the USA, Japan, and the European Union. It is likely that these regulations will be modified and tightened up with extension of reliable databases.

\section{Potential ecotoxicity of nanobased materials and processes related to water applications}

Nanomaterials in water do not directly affect humans, but there is the possibility of uptake of nanomaterials via consumption of fish, so the impact of nanomaterials on aquatic organisms needs to be taken into consideration. The harmful effects of nanomaterials on aquatic organisms are related mainly to nanoparticles, so the following section is concerned with the potential toxicity of $\mathrm{TiO}_{2}$ nanoparticles, ${ }^{67}$ silver nanoparticles, ${ }^{68}$ and CNTs, ${ }^{69,70}$ which are the most common nanoparticle species.

\section{Harmful effects on aquatic organisms}

An extensive overview of the miscellaneous effects of $\mathrm{TiO}_{2}$ nanoparticles on various kinds of aquatic organisms is given in a case study published by the US Environmental Protection Agency in 2010. ${ }^{71}$ In that study, different types of nano- $\mathrm{TiO}_{2}$, different pathways of entry, and different effects on the environment and organisms were shown by comparing several studies of the influence of nanoparticles, exemplified by $\mathrm{TiO}_{2}$, on different kinds of organisms, including bacteria, algae, invertebrates, fish, and plants. Their reported effects on aquatic organisms included decreased reproduction of daphnia as well as respiratory distress, pathological changes in the gills and in testine, and behavioral changes in fish. ${ }^{71}$ Various acute effects on algae could be demonstrated depending on the type and concentration of $\mathrm{TiO}_{2}$; however, the median effective concentration depended mainly on the size of the particles. Table 5 summarizes the results of several toxicity studies for different types of $\mathrm{TiO}_{2}$ nanoparticles, nano- $\mathrm{ZnO}$, nano- $\mathrm{CuO}$, and nano- $\mathrm{SiO}_{2}$, as well as fullerenes and CNTs and their effect on various aquatic organisms.

Another important factor when evaluating the toxicity of nanoparticles is the exposure time. For example, $\mathrm{TiO}_{2}$ exerted minimal toxicity to daphnia within the usual 48-hour exposure time, but caused high toxicity when the exposure time was extended to 72 hours. ${ }^{82}$

The toxicity of $\mathrm{CdSe} / \mathrm{ZnS}$ quantum dots to daphnia only occurs at relatively high concentrations, which is unlikely in aquatic environments. ${ }^{83}$ For example, among other $\mathrm{CdSe} / \mathrm{ZnS}$ quantum dots and red polyethylene oxide quantum dots have a relatively low median effective concentration of $0.11 \mathrm{mg} / \mathrm{L}$ and $0.06 * 10^{15}$ particles per liter, respectively. ${ }^{83}$

The toxicity of water-soluble CdTe quantum dots to unicellular green algae (Chlamydomonas reinhardtii) is one order of magnitude higher than that of $\mathrm{TiO}_{2}$ (P25). ${ }^{84}$ Oxidative stress and DNA damage induced by CdTe quantum dots to fresh water mussels (Elliptio complanata) were detected. ${ }^{85}$ The livers of sticklebacks (Gasterosteus aculeatus) exposed to $\mathrm{CdS}$ quantum dots exhibited hepatocellular nuclear pleomorphism. ${ }^{86}$

The concentration of dissolved organic matter in the aqueous environment affects the median effective and lethal concentrations of nano- $\mathrm{CuO}$ and nano- $\mathrm{ZnO}$ in crustaceae (Daphnia magna, Thamnocephalus platyurus) and protozoa (Tetrahymena thermophila). ${ }^{87}$

Rainbow trout exposed to single-walled CNTs show increased $\mathrm{Na}^{+} \mathrm{K}^{+}$-ATPase activity in the gills and intestines; however, their toxicity is more respiratory than ionoregulatory because of precipitation on the gill mucus. ${ }^{88}$ Mouchet et $\mathrm{al}^{77}$ demonstrated the toxic effect of double-walled CNTs at different concentrations in the larvae of the amphibian Xenopus laevis. Klaper et $\mathrm{al}^{89}$ suggested that fullerene nanoparticles are associated with oxidative stress responses in daphnia. Several studies show that the toxicity of $\mathrm{nC}_{60}$ to daphnia also depends on the type of solubilization, eg, waterstirred or tetrahydrofuran-solubilized. ${ }^{90-92} \mathrm{C}_{60}$ fullerenes spontaneously form aqueous colloids in water containing 
Table 5 Effects of various nanomaterials in different aquatic organisms

\begin{tabular}{|c|c|c|c|}
\hline Test species & Material & Study outcome & Reference \\
\hline $\begin{array}{l}\text { Algae (green algae, } \\
\text { Desmodesmus subpicatus) }\end{array}$ & $\begin{array}{l}\mathrm{TiO}_{2}: 20.5 \mathrm{~nm} \text { primary particle, } 20 \% \text { rutile, } 80 \% \text { anatase, } \\
\mathrm{BET} \text { surface area } 45 \mathrm{~m}^{2} / \mathrm{g} \text {; sonicated (Evonik } \mathrm{P} 25 \text { ) }\end{array}$ & $\mathrm{EC}_{50} 32-44 \mathrm{mg} / \mathrm{L}$ & 72 \\
\hline $\begin{array}{l}\text { Invertebrates (Daphnia pulex } \\
\text { and Ceriodaphnia dubia) }\end{array}$ & $\begin{array}{l}\mathrm{TiO}_{2}: 20.5 \mathrm{~nm} \text { primary particle, } 20 \% \text { rutile, } 80 \% \text { anatase, } \\
\mathrm{BET} \text { surface area } 45 \mathrm{~m}^{2} / \mathrm{g} \text {; sonicated (Evonik } \mathrm{P} 25 \text { ) }\end{array}$ & $\mathrm{LC}_{50}>10 \mathrm{mg} / \mathrm{L}$ & 73 \\
\hline Fish (zebrafish, Danio rerio) $)^{73}$ & $\begin{array}{l}\mathrm{TiO}_{2}: 20.5 \mathrm{~nm} \text { primary particle, } 20 \% \text { rutile, } 80 \% \text { anatase, } \\
\text { BET surface area } 45 \mathrm{~m}^{2} / \mathrm{g} \text {, sonicated (Evonik } \mathrm{P} 25 \text { ) }\end{array}$ & $\mathrm{LC}_{50}>10 \mathrm{mg} / \mathrm{L}$ & 73 \\
\hline $\begin{array}{l}\text { Algae (green algae, } \\
\text { Pseudokirchneriella subcapita) }\end{array}$ & $<75 \mathrm{~nm}$ primary particle of $\mathrm{TiO}_{2}$ (Sigma product 643017 ) & $\mathrm{EC}_{50}>100 \mathrm{mg} / \mathrm{L}$ & 74 \\
\hline $\begin{array}{l}\text { Algae (green algae, } \\
\text { P. subcapita) }\end{array}$ & $\begin{array}{l}\text { I } 40 \mathrm{~nm} \text { in water, } 79 \% \text { rutile, } 21 \% \text { anatase, coated } \\
\text { with alumina (ulftrafine } \mathrm{TiO} 2 \text { powder from DuPont } \\
\text { with a coating of alumina }\left[\text { DuPont uf-C } \mathrm{TiO}_{2}\right] \text { ) }\end{array}$ & $\begin{array}{l}\mathrm{EC}_{50} 21 \mathrm{mg} / \mathrm{L} \text { (cell number) } \\
\mathrm{EC}_{50} 87 \mathrm{mg} / \mathrm{L} \text { (growth rate) }\end{array}$ & 75 \\
\hline $\begin{array}{l}\text { Fish (rainbow trout, } \\
\text { Oncorhynchus mykiss) }\end{array}$ & $\begin{array}{l}\text { I } 40 \mathrm{~nm} \text { in water, } 79 \% \text { rutile, } 21 \% \text { anatase, coated } \\
\left(\text { DuPont uf- } \mathrm{C} \mathrm{TiO}_{2}\right)\end{array}$ & $\mathrm{LC}_{50}>100 \mathrm{mg} / \mathrm{L}$ & 75 \\
\hline $\begin{array}{l}\text { Algae (green algae, } \\
\text { P. subcapita) }\end{array}$ & $\begin{array}{l}\text { Fine } \mathrm{TiO}_{2}, 380 \mathrm{~nm} \text { in water rutile, coated }\left(\sim 99 \% \mathrm{TiO}_{2},\right. \\
\sim 1 \% \text { alumina })\end{array}$ & $\begin{array}{l}\mathrm{EC}_{50} 16 \mathrm{mg} / \mathrm{L} \text { (cell number) } \\
\mathrm{EC}_{50} 61 \mathrm{mg} / \mathrm{L} \text { (growth rate) }\end{array}$ & 75 \\
\hline Invertebrate (Daphnia magna) ${ }^{7}$ & $\mathrm{TiO}_{2}:$ Primary particle $<25 \mathrm{~nm}$, anatase, filtered $(0.22 \mu \mathrm{m})$ & $\begin{array}{l}\mathrm{LC}_{50} 5.5 \mathrm{mg} / \mathrm{L} \\
\text { LOEC } 2.0 \mathrm{mg} / \mathrm{L} \\
\text { NOEC } 1.0 \mathrm{mg} / \mathrm{L}\end{array}$ & 76 \\
\hline Frog larvae (Xenopus laevis) ${ }^{8}$ & $\begin{array}{l}\text { Mortality by concentrations of double-wall CNTs, } \\
\text { different concentrations }\end{array}$ & $\begin{array}{l}0 \%-15 \%(10 \mathrm{mg} / \mathrm{L}) \\
0 \%-5 \%(100 \mathrm{mg} / \mathrm{L}) \\
5 \%-85 \%(500 \mathrm{mg} / \mathrm{L})\end{array}$ & 77 \\
\hline Vibrio fisheri' & $\begin{array}{l}\text { Nano } \mathrm{TiO}_{2}: 25-70 \mathrm{~nm} \\
\text { Nano } \mathrm{ZnO}: 50-70 \mathrm{~nm} \\
\text { Nano } \mathrm{CuO}: \sim 30 \mathrm{~nm}\end{array}$ & $\begin{array}{l}\mathrm{EC}_{50}>20,000 \mathrm{mg} / \mathrm{L}\left(\mathrm{TiO}_{2}\right) \\
\mathrm{EC}_{50} \mathrm{I} .8 \pm 0.1 \mathrm{mg} / \mathrm{L}(\mathrm{ZnO}) \\
\mathrm{EC}_{50} 79 \pm 27 \mathrm{mg} / \mathrm{L}(\mathrm{CuO})\end{array}$ & 78 \\
\hline D. magna ${ }^{9}$ & $\begin{array}{l}\text { Nano } \mathrm{TiO}_{2}: 25-70 \mathrm{~nm} \\
\text { Nano } \mathrm{ZnO}: 50-70 \mathrm{~nm} \\
\text { Nano } \mathrm{CuO}: \sim 30 \mathrm{~nm}\end{array}$ & $\begin{array}{l}\mathrm{LC}_{50} \sim 20,000 \mathrm{mg} / \mathrm{L}\left(\mathrm{TiO}_{2}\right) \\
\mathrm{LC}_{50} 3.2 \pm 1.3 \mathrm{mg} / \mathrm{L}(\mathrm{ZnO}) \\
\mathrm{LC}_{50} 3.2 \pm 1.6 \mathrm{mg} / \mathrm{L}(\mathrm{CuO})\end{array}$ & 78 \\
\hline D. magna ${ }^{79}$ & $\begin{array}{l}\text { Nano-/Micro-Ag } \\
\text { Nano-/Micro- } \mathrm{CeO}_{2}\end{array}$ & $\begin{array}{l}\text { Mortality on different } \\
\text { concentrations }\end{array}$ & 79 \\
\hline Thamnocephalus platyurus ${ }^{9}$ & $\begin{array}{l}\text { Nano } \mathrm{TiO}_{2}: 25-70 \mathrm{~nm} \\
\text { Nano } \mathrm{ZnO}: 50-70 \mathrm{~nm} \\
\text { Nano } \mathrm{CuO}: \sim 30 \mathrm{~nm}\end{array}$ & $\begin{array}{l}\mathrm{LC}_{50}>20,000 \mathrm{mg} / \mathrm{L}\left(\mathrm{TiO}_{2}\right) \\
\mathrm{LC}_{50} 0.18 \pm 0.03 \mathrm{mg} / \mathrm{L}(\mathrm{ZnO}) \\
\mathrm{LC}_{50} 2.1 \pm 0.5 \mathrm{mg} / \mathrm{L}(\mathrm{CuO})\end{array}$ & 78 \\
\hline Zebrafish $(D . \text { rerio })^{80}$ & Fullerenes & $\begin{array}{l}\mathrm{LC}_{50} 200 \mathrm{ppb}\left(\mathrm{C}_{60}\right) \\
\mathrm{LC}_{50} 200 \mathrm{ppb}\left(\mathrm{C}_{70}\right) \\
\mathrm{LC}_{50} 4,000 \mathrm{ppb}\left(\mathrm{C}_{60}(\mathrm{OH})_{24}\right)\end{array}$ & 80 \\
\hline Bacillus subtilis ${ }^{81}$ & $\begin{array}{l}\text { Percentage growth inhibition of } \mathrm{TiO}_{2}(330 \mathrm{~nm}) \text {, } \\
\mathrm{SiO}_{2}(205 \mathrm{~nm}), \mathrm{ZnO}(480 \mathrm{~nm})\end{array}$ & $\begin{array}{l}75 \% \pm 6.6 \% \text { at } 1,000 \mathrm{ppm} \mathrm{TiO} \\
7 \% \pm 4.7 \% \text { at } 1,000 \mathrm{ppm} \mathrm{SiO}_{2} \\
90 \% \pm 4.4 \% \text { at } 10 \mathrm{ppm} \mathrm{ZnO}\end{array}$ & 81 \\
\hline Escherichia coli ${ }^{81}$ & $\begin{array}{l}\text { Percentage growth inhibition of } \mathrm{TiO}_{2}(330 \mathrm{~nm}) \text {, } \\
\mathrm{SiO}_{2}(205 \mathrm{~nm}), \mathrm{ZnO}(480 \mathrm{~nm})\end{array}$ & $\begin{array}{l}15 \% \pm 4.2 \% \text { at } 500 \mathrm{ppm} \mathrm{TiO}_{2} \\
15 \% \pm 6.4 \% \text { at } 500 \mathrm{ppm} \mathrm{SiO}_{2} \\
14 \% \pm 3.5 \% \text { at } 10 \mathrm{ppm} \mathrm{ZnO}\end{array}$ & 81 \\
\hline
\end{tabular}

Abbreviations: $\mathrm{EC}_{50}$, median effective concentration; $\mathrm{LC}_{50}$, median lethal concentration; LOEC, lowest observed effect concentration; NOEC, no observed effect concentration; BET, Brauner-Emmett-Teller.

nanocrystalline aggregates, which are thought to be toxic to bacteria. $^{93}$

Due to their surface structure, some CNTs have high reactivity and an ability to transport other substances into the cell body. Further, the presence of $\mathrm{C}_{60}$ suspensions alters the toxicity of phenantrene (increased) and pentachlorophenol (reduced) in algae and daphnia. ${ }^{94} \mathrm{C}_{60}$ leads to both necrotic and apoptotic cellular death. $\mathrm{C}_{60}(\mathrm{OH})_{24}$ that is significantly less toxic than $\mathrm{C}_{60}$ raised necrotic cellular death. ${ }^{79}$ Fullerenes like $\mathrm{nC}_{60}$ also impact negatively by bioaccumulation, eg, in daphnia, with an accumulation level of up to $7,000 \mathrm{mg} / \mathrm{kg}$ wet weight. ${ }^{95}$

\section{Fate and removal of nanomaterials in water}

Emission of nanoparticles into the environment may come from point sources, eg, production facilities, landfills, or wastewater treatment plants, or from nonpoint sources, such as washing machines, clothing, or other materials containing nanoparticles. ${ }^{96}$ For example, a certain amount of nanosilver is released from clothes by washing depending on the adhesion of the silver to the clothes and the specific washing conditions. Commercially available nanosocks have been shown to leach $25 \%$ of their total silver content within minutes at $\mathrm{pH} 10 .{ }^{97-99}$ 


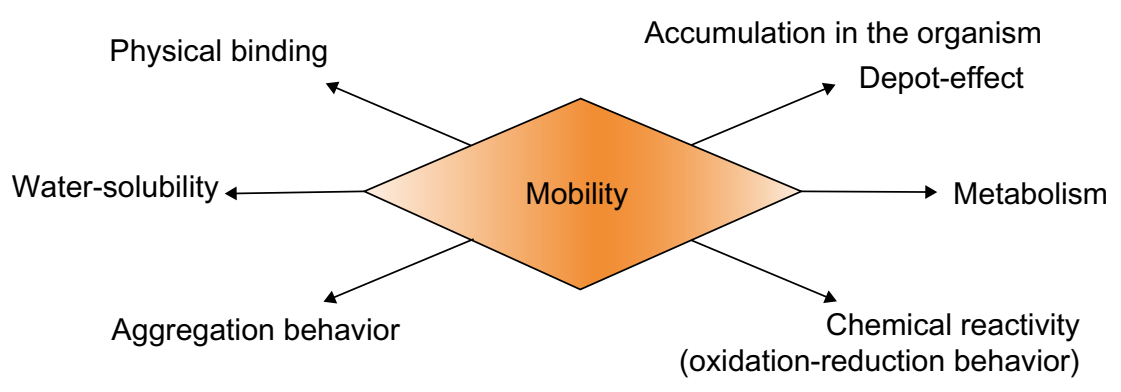

Figure 2 Properties of nanoparticles in water bodies.

The mobility of nanoparticles in water bodies as shown in Figure 2 depends on a number of their properties, such as water solubility, physical binding to other components, and their chemical reactivity, eg, oxidation and reduction behavior. These factors and the surface charge of nanoparticles may lead to immobilization.

Due to their high specific surface, most nanoparticles tend to accumulate and adsorb immediately after water contact, losing their individual nanoscale characteristics. Thereby, the surface configuration of polymers influences the agglomeration of nanoparticles in aqueous systems as well as providing interaction with different proteins. ${ }^{76,77}$ Thereby, the surface configuration of polymeric nanoparticles such as polyethylenimine influences the agglomeration in aqueous systems. Besides polymeric nanoparticles can interact with different proteins such as fetal bovine serum. ${ }^{100-102}$ As agglomerates or adsorbed to macroparticles, nanoparticles can be deposited for a long period of time in sediments of natural water bodies, like lakes or rivers, and also in large-scale industrial reservoirs. These bound nanoparticles are "inactive" but not harmless since a change of environmental conditions, for example, a rise in temperature or a decrease in $\mathrm{pH}$, might induce dissolution of the nanoparticles.

Due to the high chemical reactivity of nanometal oxides, their stability is temporarily and locally very limited, resulting in short propagation paths. However, several research groups have attempted to stabilize nanometal oxides to improve their efficacy for water remediation processes. ${ }^{30}$

There are various degradation pathways for nanoparticles in aqueous systems, depending on the specific environmental conditions. According to their physical and chemical properties, nanoparticles can be altered by sunlight-induced photoreaction depending on the turbidity of the water. Biotic or abiotic degradation processes might also occur. ${ }^{103}$ Under anaerobic conditions, certain organic and metallic nanomaterials can possibly be transformed or react to complex compounds. ${ }^{104}$

For estimating the influence of nanoparticles on the environment, various studies have been carried out comparing calculated environmental concentrations of the most common nanomaterials with data from ecotoxicity studies. In a probabilistic material flow study for the USA, Europe, and Switzerland, Gottschalk et a $\mathrm{l}^{105}$ calculated risk quotients for nanosilver, nano- $\mathrm{TiO}_{2}$, and nano- $\mathrm{ZnO}$ in sewage treatment effluents and surface water (Table 6). The risk quotient is defined as the quotient of the predicted (calculated) environmental concentration and predicted no effect concentration. Whereas the predicted environmental concentration results were taken from the study, the predicted no effect concentration values were calculated on the basis of ecotoxicity data from the literature. If the risk quotient is $\geq 1$, further testing is required, and if it is $<1$, no risk is posed to the environment and no additional measurements are necessary. ${ }^{106}$ Table 6 shows that at the time the study was prepared, ie, 2009, for all regions considered, nanosilver, nano- $\mathrm{ZnO}$, and nano- $\mathrm{TiO}_{2}$ posed marked ecotoxicity risks in sewage treatment plant effluent. The predicted environmental concentration for nanosilver was so high that even in surface

Table 6 Risk quotient for different nanoparticles in surface water and STP effluent in Europe, USA, and Switzerland

\begin{tabular}{llll}
\hline & Europe & USA & Switzerland \\
\hline & Nano-TiO & & \\
Surface water & 0.015 & 0.002 & 0.02 \\
STP effluent & 3.5 & 1.8 & 4.3 \\
& Nano-ZnO & & \\
Surface water & 0.25 & 0.02 & 0.32 \\
STP effluent & 10.8 & 7.7 & $1 \mathrm{I}$ \\
& Nanosilver & & \\
Surface water & I.I & 0.17 & 1.03 \\
STP effluent & 61.1 & 30.1 & 55.6 \\
& CNT & & \\
Surface water & $<0.0005$ & $<0.0005$ & $<0.0005$ \\
STP effluent & $<0.0005$ & $<0.0005$ & $<0.0005$ \\
& Fullerenes & & \\
Surface water & $<0.0005$ & $<0.0005$ & $<0.0005$ \\
STP effluent & 0.026 & 0.023 & 0.019 \\
\hline
\end{tabular}

Note: Reprinted with permission from Gottschalk F, Sonderer T, Scholz RW, Nowack B. Modeled environmental concentrations of engineered nanomaterials (TiO2, ZnO, Ag, CNT, fullerenes) for different regions. Environ Sci Technol. 2009;43: 9216-9222. ${ }^{105}$ Copyright (C) 2009, American Chemical Society.

Abbreviation: STP, sewage treatment plant. 
water harmful effects cannot be ruled out. According to this study, fullerenes and CNT have no toxic effects, regardless of the examination area.

Wastewater treatment technologies include, besides biological treatment, various well established processes such as flocculation, sedimentation, and filtration processes that are partly implemented in municipal wastewater treatment plants. In general, the removal of nanoparticles takes place via biological treatment through interaction with the microbiological community that might degrade or incorporate nanoparticles and sedimentation. Since the settling rate decreases with smaller particle diameters, efficient sedimentation of nanoparticles requires an early agglomeration step. As mentioned earlier, due to their high specific surface, nanoparticles tend to form relatively large particle clusters or to adsorb on bigger particles, assisting the nanoparticles to separate. ${ }^{107}$ If the particles do not aggregate spontaneously, one can add appropriate surfactants during flocculation that induce formation of larger clusters. Afterwards, the nanoparticles will be removed by sedimentation, filtration, or flotation. For example, colloidal aggregates of $\mathrm{C}_{60}$ can be easily removed by the described process. ${ }^{108}$

\section{Conclusion and future prospects}

There is a significant need for novel advanced water technologies, in particular to ensure a high quality of drinking water, eliminate micropollutants, and intensify industrial production processes by the use of flexibly adjustable water treatment systems. Nanoengineered materials, such as nanoadsorbents, nanometals, nanomembranes, and photocatalysts, offer the potential for novel water technologies that can be easily adapted to customer-specific applications. Most of them are compatible with existing treatment technologies and can be integrated simply in conventional modules. One of the most important advantages of nanomaterials when compared with conventional water technologies is their ability to integrate various properties, resulting in multifunctional systems such as nanocomposite membranes that enable both particle retention and elimination of contaminants. Further, nanomaterials enable higher process efficiency due to their unique characteristics, such as a high reaction rate.

However, there are still several drawbacks that have to be negotiated. Materials functionalized with nanoparticles incorporated or deposited on their surface have risk potential, since nanoparticles might release and emit to the environment where they can accumulate for long periods of time. Up until now, no online monitoring systems exist that provide reliable real-time measurement data on the quality and quantity of nanoparticles present only in trace amounts in water, thus offering a high innovation potential. In order to minimize the health risk, several national and international regulations and laws are in preparation. Another more technical limitation of nanoengineered water technologies is that they are rarely adaptable to mass processes, and at present, in many cases are not competitive with conventional treatment technologies. Nevertheless, nanoengineered materials offer great potential for water innovations in the coming decades, in particular for decentralized treatment systems, point-of-use devices, and heavily degradable contaminants.

\section{Disclosure}

The authors report no conflicts of interest in this work.

\section{References}

1. Bruinsma J. By how much do land, water and crop yields need to increase by 2050 ? The resource outlook to 2050. Presented at the Food and Agriculture Organization of the United Nations Expert Meeting entitled "How to Feed the World in 2050", Rome, Italy, June 24-26, 2009.

2. World Water Development Report 4. Managing water under uncertainty and risks, 2014. Available from: http://www.unesco.org/new/en/naturalsciences/environment/water/wwap/wwdr/wwdr4-2012. Accessed July 24, 2014.

3. Schewe J, Heinke J, Gerten D, et al. Multimodel assessment of water scarcity under climate change. Proc Natl Acad Sci U S A. 2013;111: 3245-3250.

4. Encyclopaedia Britannica. Adsorption. Available from: http://www. britannica.com/EBchecked/topic/6565/adsorption. Accessed April 9, 2014.

5. Pan B, Xing BS. Adsorption mechanisms of organic chemicals on carbon nanotubes. Environ Sci Technol. 2008;42:9005-9013.

6. Rao GP, Lu C, Su F. Sorption of divalent metal ions from aqueous solution by carbon nanotubes: a review. Separation and Purification Technology. 2008;58:224-231.

7. Liu X, Wang M, Zhang S, Pan B. Application potential of carbon nanotubes in water treatment: a review. J Environ Sci (China). 2013;25: S1263-S1280.

8. Yan HY, Han ZJ, Yu SF, Pey KL, Ostrikov K, Karnik R. Carbon nanotube membranes with ultrahigh specific adsorption capacity for water desalination and purification. Nat Commun. 2013;4:2220.

9. Hashim DP, Narayanan NT, Romo-Herrera JM, et al. Covalently bonded three-dimensional carbon nanotube solids via boron induced nanojunctions. Sci Rep. 2012;2:363.

10. De Volder MF, Tawfick SH, Baughman RH, Hart J. Carbon nanotubes: present and future commercial applications. Science. 2013;339: 535-539.

11. Ji L, Chen W, Duan L, Zhu D. Mechanisms for strong adsorption of tetracycline to carbon nanotubes: a comparative study using activated carbon and graphite as adsorbents. Environ Sci Technol. 2009;43: 2322-2327.

12. Cong Q, Yuan X, Qu J. A review on the removal of antibiotics by carbon nanotubes. Water Sci Technol. 2013;68:S1679-S1687.

13. Qu X, Alvarez PJ, Li Q. Applications of nanotechnology in water and wastewater treatment. Water Res. 2013;47:3931-3946.

14. Hajeh M, Laurent S, Dastafkan K. Nanoadsorbents: classification, preparation, and applications (with emphasis on aqueous media). Chem Rev. 2013;113:S7728-S7768.

15. Diallo MS, Christie S, Swaminathan P, Johnson JH, Goddard WA. Dendrimer enhanced ultrafiltration. 1. Recovery of $\mathrm{Cu}$ (II) from aqueous solutions using PAMAM dendrimers with ethylenediamine core and terminal $\mathrm{NH}_{2}$ groups. Environ Sci Technol. 2005;39:S1366-S1377. 
16. Sadeghi-Kiakhani M, Mokhtar Arami M, Gharanjig K. Dye removal from colored-textile wastewater using chitosan-PPI dendrimer hybrid as a biopolymer: optimization, kinetic, and isotherm studies. $J \mathrm{Appl}$ Polym Sci. 2013;127:2607-2619.

17. Baker MD, Ozin GA, Godber J. Far-infrared studies of silver atoms, silver ions, and silver clusters in zeolites A and Y. J Phys Chem. 1985;89: 305-311.

18. Egger S, Lehmann RP, Height MJ, Loessner MJ, Schuppler M. Antimicrobial properties of a novel silver-silica nanocomposite material. Appl Environ Microbiol. 2009;75:2973-2976.

19. Nagy A, Harrison A, Sabbani S, Munson RS Jr, Dutta PK, Waldman WJ. Silver nanoparticles embedded in zeolite membranes: release of silver ions and mechanism of antibacterial action. Int J Nanomedicine. 2011;6: 1833-1852.

20. Petrik L, Missengue R, Fatoba M, Tuffin M, Sachs J. Silver/zeolite nano composite-based clay filters for water disinfection. Report to the Water Research Commission. No KV 297/12. Available from: http:// www.ircwash.org/resources/silver-zeolite-nano-composite-based-clayfilters-water-disinfection. Accessed July 24, 2014.

21. Tiwari DK, Behari J, Sen P. Application of nanoparticles in waste water treatment. World Applied Sciences Journal. 2008;3:417-433.

22. Jung JY, Chung YC, Shin HS, Son DH. Enhanced ammonia nitrogen removal using consistent biological regeneration and ammoniumexchange of zeolite in modified SBR process. Water Res. 2004;38: 347-354.

23. Aredes S, Klein B, Pawlik M. The removal of arsenic from water using natural iron oxide minerals. Journal of Cleaner Production. 2012;29-30:208-213.

24. Nowack B, Krug HF, Height M. 120 years of nanosilver history: implications for policy makers. Environ Sci Technol. 2011;45: 1177-1183.

25. Kim ES, Hwang G, El-Din MG, Liu Y. Development of nanosilver and multi-walled carbon nanotubes thin-film nanocomposite membrane for enhanced water treatment. J Memb Sci. 2012;394:37-48.

26. Nora S, Mamadou SD. Nanomaterials and water purification: opportunities and challenges. J Nanopart Res. 2005;7:331-342.

27. Quang DV, Pradi B, Sarawade, SJ, et al. Effective water disinfection using silver nanoparticle containing silica beads. Appl Surf Sci. 2013;287:84-90

28. Gupta AK, Deva D, Sharma A, Verma N. Fe-grown carbon nanofibers for removal of arsenic (V) in wastewater. Ind Eng Chem Res. 2010;49: 7074-7084.

29. Kim YC, Han S, Hong S. A feasibility study of magnetic separation of magnetic nanoparticle for forward osmosis. Water Sci Technol. 2011;64: 469-476.

30. Matlochova A, Plachá D, Rapantová N. The application of nanoscale materials in groundwater remediation. Pol J Environ Stud. 2014;22: 1401-1410.

31. Homhoul P, Pengpanich S, Hunsom M. Treatment of distillery wastewater by the nano-scale zero-valent iron and the supported nanoscale zero-valent iron. Water Environ Res. 2011;83:65-74.

32. Jagadevan S, Jayamurthy M, Dobson P, Thompson IPA. Novel hybrid nano zerovalent iron initiated oxidation - biological degradation approach for remediation of recalcitrant waste metalworking fluids. Water Res. 2012;46:2395-2404.

33. Sharma V, Sharma A. Nanotechnology: an emerging future trend in wastewater treatment with its innovative products and processes. International Journal of Enhanced Research in Science Technology and Engineering. 2012;1:121-128.

34. Wegmann M, Michen B, Graule T. Nanostructured surface modification of microporous ceramics for efficient virus filtration. J Eur Ceram Soc. 2008;28:1603-1612.

35. Feng C, Khulbe KC, Matsuura T, Tabe S, Ismail AF. Preparation and characterization of electro-spun nanofiber membranes and their possible applications in water treatment. Separation and Purification Technology. 2013;102:118-135.

36. Kim ES, Deng B. Fabrication of polyamide thin-film nano-composite (PA-TFN) membrane with hydrophilized ordered mesoporous carbon (H-OMC) for water purifications. J Memb Sci. 2011;375:46-54.
37. Fathizadeh M, Aroujalian A, Raisi A. Effect of added NaXnano-zeolite into polyamide as a top thin layer of membrane on water flux and salt rejection in a reverse osmosis process. J Memb Sci. 2011;375:88-95.

38. Gehrke I, Keuter V, Groß F. Development of nanocomposite membranes with photocatalytic surfaces. J Nanosci Nanotechnol. 2012;12: 9163-9168.

39. Gehrke I. Environmental friendly recycling of strategic metals. Fraunhofer UMSICHT Annual Report. 2013. Available from: http:// www.umsicht.fraunhofer.de/content/dam/umsicht/en/documents/ annual\%20reports/2013-annual-report.pdf. Accessed July 24, 2014.

40. Whitesides GM, Grzybowski B. Self-assembly at all scales. Science. 2002;295:2418-2421.

41. Qiu X, Yu H, Karunakaran M, Pradeep N, Nunes SP, Peinemann KV. Selective separation of similarly sized proteins with tunable nanoporous block copolymer membranes. ACS Nano. 2013;7:768-776.

42. Pendergast MT, Dorin RM, Phillip WA, Wiesner U, Hoek EM. Understanding the structure and performance of self-assembled triblock terpolymer membranes. J Memb Sci. 2013;444:461-468.

43. Cloete TE, de Kwaadsteniet M, Botes M, Lopez-Romero JM. Nanotechnology in Water Treatment Applications. Norfolk, UK: Caister Academic Press; 2010.

44. Ramakrishna S, Fujihara K, Teo WE, Yong T, Ma ZW, Ramaseshan R. Electrospun nanofibers: solving global issues. Mater Today. 2006;9: 40-50.

45. Karim MR, Rhodes ER, Brinkman N, Wymer L, Shay Fout G. New electropositive filter for concentrating enteroviruses and noroviruses from large volumes of water. Appl Environ Microbiol. 2009;75:2393-2399.

46. Tang CY, Zhao Y, Wang R, Hélix-Nielsen C, Fane AG. Desalination by biomimetic aquaporin membranes: review of status and prospects. Desalination. 2013;308:34-40.

47. Xie W, He F, Wang B, et al. An aquaporin-based vesicle-embedded polymeric membrane for low energy water filtration. J Mater Chem A. 2013;1:7592-7600.

48. Espinoza LA. Heterogeneous photocatalysis with titanium dioxide suspensions containing bromide and dissolved organic carbon. In: Band 51, Schriftenreihe des Lehrstuhls für Wasserchemie und der DVGWForschungsstelle am Engler-Bunte-Institut des Karlsruher Instituts für Technologie (KIT), [DVGW-series, Karlsruher Institute of Technology] Karlsruhe 2010. German.

49. Friedmann D, Mendiveb C, Bahnemann D. $\mathrm{TiO}_{2}$ for water treatment: parameters affecting the kinetics and mechanisms of photocatalysis. Appl Catal B Environ. 2010;99:398-406.

50. Chong MN, Jin B, Chow CW, Saint C. Recent developments in photocatalytic water treatment technology: a review. Water Res. 2010;44: 2997-3027.

51. Fujishima A, Zhang X, Tryk DA. TiO2 photocatalysis and related surface phenomena. Surf Sci Rep. 2008;63:515-582.

52. Gaya UI, Abdullah AH. Heterogeneous photocatalytic degradation of organic contaminants over titanium dioxide: a review of fundamentals, process and problems. J Photochem Photobiol A Chem. 2008;9:1-12.

53. Meng ZD, Zhu L, Ye S, et al. Fullerene modification $\mathrm{CdSe} / \mathrm{TiO}_{2}$ and modification of photocatalytic activity under visible light. Nanoscale Res Lett. 2013;8:189-199.

54. Meng ZD, Zhu L, Choi JC, Park CY, Oh WC. Preparation, characterization and photocatalytic behavior of WO3-fullerene/ $\mathrm{TiO}_{2}$ catalysts under visible light. Nanoscale Res Lett. 2011;6:459.

55. Lazar MA, Varghese S, Nair SS. Photocatalytic water treatment by titanium dioxide: recent updates. Catalysts. 2012;2:572-601.

56. Azrague K, Aimar P, Benoit-Marquié F, Maurette MT. A new combination of a membrane and a photcatalytic reactor for the depollution of turbid water. Appl Catal B Environ. 2007;72:197-204.

57. Ollis DF. Integrating photocatalysis and membrane technologies for water treatment. Ann N Y Acad Sci. 2003;984:65-84.

58. Keuter V. Development of multi-barrier systems consisting of nanoenhanced membranes and UV-LEDs for water purification applications. Abstract presented at the Euromembrane 2012 Conference, London, UK, September 23-27, 2012. 
59. [No authors listed]. Purifics' Photo-Cat cleans up contaminated groundwater. Membrane Technology. 2011;9:6.

60. Nano.gov. What is the NNI? 2014. Available from: http://www.nano. gov/about-nni/what. Accessed April 16, 2014.

61. Horizon 2020. Work Programme 2014-2015. 5. Leadership in enabling and industrial technologies. II. Nanotechnologies, Advanced Materials, Biotechnology and Advanced Manufacturing and Processing. Available from: http://ec.europa.eu/research/participants/data/ref/ h2020/wp/2014_2015/main/h2020-wp1415-leit-nmp_en.pdf. Accessed July 24, 2014.

62. Horizon 2020. Work Programme 2014-2015. 12. Climate action, environment, resource efficiency and raw materials. Available from: http://ec.europa.eu/research/horizon2020/pdf/work-programmes/ climate_action_environment_resource_efficiency_and_raw_materials_ draft_work_programme.pdf. Accessed July 24, 2014.

63. European Parliament and Council. Regulation (EC) No 1907/2006 of the European Parliament and of the Council of 18 December 2006 concerning the Registration, Evaluation, Authorisation and Restriction of Chemicals (REACH), establishing a European Chemicals Agency. Available from: http://eur-lex.europa.eu/legal-content/EN/ALL/ELX_ SESSIONID=GctYTQvNMZSqByV11X23LRQSM0JpVbD2gTFpbL NTKKRlfJLB2tym!-1120470413?uri=CELEX:32006R1907. Accessed July 24, 2014

64. European Commission. Commission Recommendation of 18 October 2011 on the definition of nanomaterial (2011/696/EU). Available from: http://eur-lex.europa.eu/LexUriServ/LexUriServ.do?uri=OJ:L:2011:27 5:0038:0040:EN:PDF. Accessed July 24, 2014.

65. European Parliament and Council. Directive 2000/60/EC of the European Parliament and of the Council of 23 October 2000 establishing a framework for Community action in the field of water policy. Available from: http://eur-lex.europa.eu/legal-content/EN/ TXT/?uri=CELEX:32000L0060. Accessed July 24, 2014.

66. US Environmental Protection Agency. Nanotechnology: an EPA research perspective. 2007. Available from: http://www.epa.gov/ncer/ nano/factsheet/nanofactsheetjune07.pdf. April 16, 2014.

67. Clemente Z, Castro VL, Jonsson CM, Fraceto LF. Ecotoxicology of Nano- $\mathrm{TiO}_{2}$ - an evaluation of its toxicity to organisms of aquatic ecosystems. Int J Environ Res. 2011;6:33-50.

68. Asghari S, Johari SA, Lee JH, et al. Toxicity of various silver nanoparticles compared with silver ions in Daphnia magna. J Nanobiotechnology. 2012;10:14.

69. Petersen EJ, Zhang L Mattison NT, et al. Potential release pathways, environmental fate, and ecological risks of carbon nanotubes. Environ Sci Technol. 2011;45:9837-9856.

70. Jackson P, Jacobsen NR, Baun A, et al. Bioaccumulation and ecotoxicity of carbon nanotubes. Chem Cent J. 2013,7:154.

71. European Protection Agency. RTP Division. Nanomaterial case studies: nanoscale titanium dioxide in water treatment and in topical sunscreen. 2010; EPA/600/R-09/057F. Available from: http://cfpub.epa.gov/ncea/ $\mathrm{cfm} /$ recordisplay.cfm?deid=230972. Accessed July 24, 2014.

72. Hund-Rinke K, Simon M. Ecotoxic effect of photocatalytic active nano particles (TiO2) on algae and daphnids. Environ Sci Pollut Res Int. 2006; 13:225-232.

73. Griffitt RJ, Luo J, Gao J, Bonzongo JC, Barber DS. Effects of particle composition and species on toxicity of metallic nanomaterials in aquatic organisms. Environ Toxicol Chem. 2008;29: 1972-1978.

74. Velzeboer I, Hendriks AJ, Ragas AM, van de Meent D. Aquatic ecotoxicity tests of some nanomaterials. Environ Toxicol Chem. 2008;27: 1942-1947.

75. Warheit DB, Hoke RA, Finlay C, Donner EM, Reed KL, Sayes CM. Development of a base set of toxicity tests using ultrafine $\mathrm{TiO}_{2}$ particles as a component of nanoparticle risk management. Toxicol Lett. 2007;171:99-110.

76. Lovern SB, Klaper R. Daphnia magna mortality when exposed to titanium dioxide and fullerene (C60) nanoparticles. Environ Toxicol Chem. 2006;25:1132-1137.
77. Mouchet F, Landois P, Sarremejean E, et al. Characterization and in vivo ecotoxicity evaluation of double-wall carbon nanotubes in larvae of the amphibian Xenopus laevis. Aquat Toxicol. 2008;87:127-137.

78. Hainlaan M, Ivask A, Blinova I, Dubourguier HC, Kahru A. Toxicity of nanosized and bulk $\mathrm{ZnO}, \mathrm{CuO}$ and $\mathrm{TiO}_{2}$ to bacteria Vibrio fischeri and crustaceans Daphnia magna and Thamnocephalus platyurus. Chemosphere. 2008;71:1308-1316.

79. Gaiser BK, Biswas A, Rosenkranz P, et al. Effects of silver and cerium dioxide micro- and nano-sized particles on Daphnia magna. J Environ Monit. 2011;13:1227-1235.

80. Usenko CY, Harper SL, Tanguay RL. In vivo evaluation of carbon fullerene toxicity using embryonic zebrafish. Carbon. 2007;45: 1891-1898.

81. Adams LK, Lyon DY, Alvarez PJ. Comparative eco-toxicity of nanoscale $\mathrm{TiO}_{2}, \mathrm{SiO}_{2}$, and $\mathrm{ZnO}$ water suspensions. Water Res. 2006;40: $3527-3532$.

82. Zhu X, Chang Y, Chen Y. Toxicity and bioaccumulation of $\mathrm{TiO}_{2}$ nanoparticle aggregates in Daphnia magna. Chemosphere. 2010;78:209-215.

83. Pace HE, Lesher EK, Ranville J. Influence of stability on the acute toxicity of CdSe/ZnS nanocrystals to Daphnia magna. Environ Toxicol Chem. 2010;29:1338-1344.

84. Wang J, Zhang X, Chen Y, Sommerfeld M, Hu Q. Toxicity assessment of manufactured nanomaterials using the unicellular green alga Chlamydomonas reinhardtii. Chemosphere. 2008;73:1121-1128.

85. Gagné F, Auclair J, Turcotte P, et al. Ecotoxicity of CdTe quantum dots to freshwater mussels: impacts on immune system, oxidative stress and genotoxicity. Aquat Toxicol. 2008;86:333-340.

86. Sanders MB, Sebire M, Sturve J et al. Exposure of sticklebacks (Gasterosteus aculeatus) to cadmium sulfide nanoparticles: biological effects and the importance of experimental design. Mar Environ Res. 2008;66:161-163.

87. Blinova I, Ivask A, Hainlaan M, Mortimer M, Kahru A. Ecotoxicity of nanoparticles of $\mathrm{CuO}$ and $\mathrm{ZnO}$ in natural water. Environ Pollut. 2010;158:41-47.

88. Smith C, Shaw BJ, Handy RD. Toxicity of single walled carbon nanotubes to rainbow trout, (Oncorhynchus mykiss): respiratory toxicity, organ pathologies, and other physiological effects. Aquat Toxicol. 2007;82:94-109.

89. Klaper R, Crago J, Barr J, Arndt D, Setyowati K, Chen J. Toxicity biomarker expression in daphnids exposed to manufactured nanoparticles: changes in toxicity with functionalization. Environ Pollut. 2009;157: $1152-1156$.

90. Zhu S, Oberdörster E, Haasch ML. Toxicity of an engineered nanoparticle (fullerene, $\mathrm{C}_{60}$ ) in two aquatic species, Daphnia and fathead minnow. Mar Environ Res. 2006;62:5-9.

91. Spohn P, Hirsch C, Hasler F, Bruinink A, Krug HF, Wick P. $\mathrm{C}_{60}$ fullerene: a powerful antioxidant or a damaging agent? The importance of an in-depth material characterization prior to toxicity assays. Environ Pollut. 2009;157:1134-1139.

92. Fries R, Greßler S, Simko M. Kohlenstoff-Nanoröhrchen - Teil II: Risiken und Regulierung. [Carbon nanotubes - Part II: Risks and regulation]. NanoTrust-Dossiers. 2011;24. German.

93. Fortner JD, Lyon DY, Sayes CM, et al. C60 in water: nanocrystal formation and microbial response. Environ Sci Technol. 2005;39: $4307-4316$

94. Baun A, Sørensen SN, Rasmussen RF, Hartmann NB, Koch CB. Toxicity and bioaccumulation of xenobiotic organic compounds in the presence of aqueous suspensions of nano- $\mathrm{C}_{60}$. Aquat Toxicol. 2008;86:379-387.

95. Tao X, Fortner JD, Zhang B, He Y, Chen Y, Hughes JB. Effects of aqueous stable fullerene nanocrystals $\left(\mathrm{nC}_{60}\right)$ an Daphnia magna: evaluation of sub-lethal reproductive responses and accumulation. Chemosphere. 2009;77:1482-1487.

96. Nowack B, Bucheli T. Occurrence, behavior and effects of nanoparticles in the environment. Environ Pollut. 2007;150:5-22.

97. Geranio L, Heuberger M, Nowack B. The behavior of silver nanotextiles during washing. Environ Sci Technol. 2009;43:8113-8118. 
98. Xiu Z, Zhang Q, Puppala HL, Colvin VL, Alvarez PJ. Neglible particle-specific antibacterial activity of silver nanoparticles. Nano Lett. 2012;12:4271-4275.

99. Damm C, Münstedt H. Kinetic aspects of the silver ion release from antimicrobial polyamide/silver nanocomposites. Appl Phys A. 2008;91: 479-486.

100. Oberdörster G, Oberdörster E, Oberdörster J. Nanotoxicology: an emerging discipline evolving from studies of ultrafine particles. Environ Health Perspect. 2005;113:823-839.

101. Rauscher H, Ansell J, Araki D, et al; for ICCR Working Group. Characterization of Nanomaterials II - insolubility, biopersistence and size measurement in complex media. Report for the ICCR. 2012. Available from: http://www.fda.gov/downloads/Cosmetics/ InternationalActivities/ICCR/UCM348951.pdf. Accessed July 24, 2014.

102. Wiogo HT, Lim M, Bulmus V, Gutiérrez L, Woodward RC, Amal R. Insight into serum protein interactions with functionalized magnetic nanoparticles in biological media. Langmuir. 2012;28:4346-4356.

103. Environmental Protection Agency. Office of the Science Advisor. Nanotechnology White Paper. EPA100/B-07/001. Washington, DC, USA: Environmental Protection Agency; 2007.
104. Nurmi JT, Tratnyek PG, Sarathy V, et al. Characterization and properties of metallic iron nanoparticles: spectroscopy, electrochemistry and kinetics. Environ Sci Technol. 2005;39:1221-1230.

105. Gottschalk F, Sonderer T, Scholz RW, Nowack B. Modeled environmental concentrations of engineered nanomaterials $\left(\mathrm{TiO}_{2}\right.$, $\mathrm{ZnO}, \mathrm{Ag}, \mathrm{CNT}$, fullerenes) for different regions. Environ Sci Technol. 2009;43:9216-9222.

106. European Chemicals Bureau. Technical Guidance Document on Risk Assessment. Dublin, UK: Institute for Health and Consumer Protection, European Commission; 2003. Available from: http://echa.europa. eu/documents/10162/16960216/tgdpart2_2ed_en.pdf. Accessed July 24, 2014.

107. European Protection Agency. Office of Research. Nanomaterial case study: nanoscale silver in disinfectant spray. EPA/600/R-10/081F, 2012. Available from: http://cfpub.epa.gov/ncea/cfm/recordisplay. cfm?deid=24166. Accessed July 24, 2014.

108. Hyung $\mathrm{H}, \mathrm{Kim} \mathrm{JH}$. Dispersion of $\mathrm{C}_{60}$ in natural water and removal by conventional drinking water processes. Water Res. 2009;43: 2463-2470.
Nanotechnology, Science and Applications

\section{Publish your work in this journal}

Nanotechnology, Science and Applications is an international, peer-reviewed, open access journal that focuses on the science of nanotechnology in a wide range of industrial and academic applications. It is characterized by the rapid reporting across all sectors, including engineering, optics, bio-medicine, cosmetics, textiles, resource sustainability and science. Applied research into nano-materials,

\section{Dovepress}

particles, nano-structures and fabrication, diagnostics and analytics, drug delivery and toxicology constitute the primary direction of the journal. The manuscript management system is completely online and includes a very quick and fair peer-review system, which is all easy to use. Visit http://www.dovepress.com/ testimonials.php to read real quotes from published authors.

Submit your manuscript here: http://www.dovepress.com/nanotechnology-science-and-applications-journal 